Historia Slavorum Occidentis

2021, nr 2 (29)

ISSN 2084-1213

DOI: $10.15804 /$ hso210211

Jan Pešina (Poznań)

ORCID: 0000-0002-0624-1433

\title{
Petr Jokeš, Czesi. Przewodnik po historii narodu i państwa, Wydawnictwo Avalon, Kraków 2020, ss. 416
}

Historia Czech cieszy się trwałym zainteresowaniem polskich historyków, niemniej brakowało w Polsce aż dotąd jej współczesnego opracowania w ujęciu syntetycznym ${ }^{1}$. Z tym większym zainteresowaniem należało sięgnąć po nową pozycję na polskim rynku wydawniczym, książkę Petra Jokeša, z wykształcenia historyka ${ }^{2}$ i bohemisty, który pracuje jako wykładowca w Instytucie Filologii Słowiańskiej Uniwersytetu Jagiellońskiego.

Jak autor zaznacza na wstępie, jego tekst jest m.in. owocem doświadczenia nabytego podczas zajęć z historii Czech prowadzonych na slawistykach we Wrocławiu i Krakowie, co umożliwiło mu „lepiej zrozumieć oczekiwania i potrzeby potencjalnego polskiego czytelnika” (s. 17). Tak więc mimo że praca, na co autor również zwraca uwagę, nie zajmuje się stosunkami czesko-polskimi, uwzględnia, w miarze odpowiadającej jego znaczeniu w ramach historii Czech, również kontekst polski,

1 Ze starszych opracowań wymieńmy pracę R. Hecka i M. Orzechowskiego, Historia Czechosłowacji, Wrocław-Warszawa-Kraków 1969; w serii wydawniczej „Historia państw świata w XX wieku” ukazała się książka J. Tomaszewskiego, Czechy i Słowacja, Warszawa 2006; z kolei w serii „Początki państw” ukazała się praca M. Matli, Czechy, Poznań 2014; w tym samym roku co recenzowana książka ukazała się w Polsce synteza J. Rychlíka i W. Penczewa, Historia Czech (tłum. A. Kawecka, M. Czyżniewski), Wrocław 2020.

2 Dr Petr Jokeš, mediewista, do obszaru jego zainteresowań naukowych należą kult świętych w średniowieczu, szczególnie wezwania kościołów, oraz organizacja kościoła w średniowieczu. Jest autorem kilkunastu artykułów naukowych oraz książki Farní organizace na středověké západní Moravě, Matice Moravská, Brno 2011. 
ale także szerzej środkowoeuropejski, europejski czy też światowy. Wiodąca perspektywą, z której badacz prowadzi swoją narrację, pozostaje perspektywa czeska - w ujęciu etnicznym (historia narodu) jak również terytorialnym (historia państwa), co wydaje się istotne ze względu na wieloetniczny (czesko-niemiecko-żydowski) charakter ziem czeskich od początku ich historii aż do połowy XX w. Na wyżej wspomnianą genezę pracy wskazuje także jej klarowna i przemyślana kompozycja: rozległą materię historyczną przedstawiono w pięćdziesięciu jeden przejrzystych, objętościowo zrównoważonych rozdziałach, których tekst wzbogacono licznymi rysunkami, fotografiami i mapkami (nieraz uzupełnionymi obszerniejszym komentarzem). Na uwagę zasługują także graficznie wydzielone teksty wzbogacające główną narrację o bardziej szczegółowe informacje - portrety ważnych postaci, dogłębne omówienia wydarzeń czy zjawisk lub wglądy do życia codziennego. Opis poprowadzono od czasów prehistorycznych do rozpadu Czechosłowacji w $1993 \mathrm{r}$.

Za istotny z punktu widzenia polskiego czytelnika należy uznać krótki rozdział wprowadzający pt. „Kraj w środku Europy”. Autor zwraca bowiem uwagę na różny zasięg nazwy Čechy/Czechy w języku czeskim i polskim. Podczas gdy w pierwszym przypadku chodzi o oznaczenie zachodniej części kraju (jednej krainy historycznej), natomiast jednosłownej, powszechnie akceptowanej nazwy właściwie do dziś brakuje, w języku polskim jest sytuacja odwrotna, bo używając nazwy Czechy, mamy na myśli cały kraj, natomiast nie ma nazwy jednoznacznie kojarzonej z Czechami właściwymi (bez Moraw i części Śląska). Wobec tego autor stara się pisać tak, by z tekstu jasno wynikało, kiedy mówi o całym kraju, a kiedy tylko o jego zachodniej części.

Przystępując do opisu historycznego, autor poświęca najpierw zwięzły rozdział najstarszym czasom na ziemiach czeskich, tzn. epokom kamienia, brązu i żelaza, reprezentowanym przez takie znaleziska archeologiczne, jak: jaskinia Šipka, Předmostí u Přerova, Dolní Věstonice lub Býč́ skála. Dalej czytamy o Celtach, pierwszym znanym z nazwy etnikum zamieszkującym ziemie czeskie w młodszym okresie epoki żelaza. Tu szczególnie ważna jest informacja o celtyckim plemieniu Bojów, od którego Rzymianie nazywali Czechy ziemią Bojów, Boiohaemum, stąd też łacińska nazwa kraju Bohemia. Rozdział zamyka krótka informacja o plemionach germańskich na terenie Czech i Moraw oraz o pojawieniu się Słowian w okresie Wielkiej wędrówki ludów.

Rozpoczynając opowieść o słowiańskich dziejach na terenie dzisiejszych Czech, autor nie zapomina o czeskim micie początku (mit o praojcu Czechu), który, jak słusznie zauważa, „do dziś jest nieodłączną częścią wyobrażeń Czechów o własnej 
przeszłości” (s. 26), zapewne dzięki jego historiograficznym i literackim utrwaleniom w ogólnej świadomości (zwłaszcza zbeletryzowanej wersji w Starych podaniach czeskich Aloisa Jiráska). Po krótkim omówieniu wydarzeń historycznych w VIVIII w. (słabo zresztą udokumentowanych w źródłach) badacz przystępuje do opisu historii Wielkich Moraw, która przypada na IX w. Okres ten, choć z właściwymi dziejami Czech powiązany tylko luźno (częściowo terytorialnie oraz powielaniem pewnych wzorców organizacji administracyjnej i kościelnej), cieszy się w historiografii czeskiej tradycyjnie dużym zainteresowaniem, co znajduje odbicie również w omawianej pracy (s. 29-39).

Począwszy od rozdziału pt. „Awans Czech” (s. 40), przenosimy się na grunt historii państwa czeskiego - ulegającego na przestrzeni kolejnych wieków zmianom terytorialnym oraz ustrojowym. Autor strukturuje swoją narrację nie tylko chronologicznie, lecz także problemowo. Opisując zjawiska, wydarzenia i postaci historyczne, nie traci z pola widzenia ich zmiennej percepcji w historiografii, opracowaniach artystycznych lub też, szerzej ujmując, w czeskim dyskursie tożsamosciowym. Jako przykład niech posłużą postaci trzech czeskich władców średniowiecza.

Pierwszy to św. Wacław (s. 41-45), czeski książę, ale przede wszystkim główny patron kraju, będący przez wieki gwarantem ciągłości państwowości czeskiej (wiecznym władcą na niebiosach), od XIX w. zaś poddawany krytycznym ocenom pod kątem aktualnych czesko-niemieckich zmagań narodowościowych. Kolejną wielowarstwową postacią jest Przemysł II Ottokar (s. 77-84), „król żelazny i złoty”, który, jak autor zauważa, jest w Czechach tradycyjnie i nieco bezkrytycznie postrzegany jako jeden z największych czeskich władców. I tak np. znaczne (lecz równocześnie krótkotrwałe) zdobycze terytorialne skłaniają, także niektórych czeskich historyków, do mówienia, nieco na wyrost, o imperium (czes. ř́še) Przemysła II Ottokara. Uwagę nie tylko historyków, lecz także artystów zapewne przyciągają dramatyczne losy życiowe (spektakularny wzlot i upadek) czeskiego króla, Jokeš natomiast najwyżej ceni (co wydaje się słuszne z dzisiejszego punktu widzenia) znaczną aktywność założycielską czeskiego władcy, której owocem były fundacje licznych miast, zamków i klasztorów. Wyjątkową pozycją w historiografii, jak również w powszechnej świadomości cieszy się w Czechach „ojciec ojczyzny”, król i cesarz Karol IV z dynastii Luksemburgów (s. 99-106). Lista dokonań tego władcy, zwłaszcza w pierwszych latach jego rządów, jest rzeczywiście imponująca. Wymieńmy chociażby założenie uniwersytetu praskiego w 1348 r., lokację nowej, rozległej dzielnicy Pragi - Nowego Miasta lub wprowadzenie instytucji Korony czeskiej, ciała jednoczącego wszystkie ziemie pod panowaniem czeskiego króla, włącznie z niedawno (w 1335 r.) przyłą- 
czonym Śląskiem. Temu regionowi historycznemu autor słusznie poświęca w swojej pracy sporo uwagi, gdyż współistniał on z Czechami w jednym organizmie państwowym ponad cztery wieki. Jak autor trafnie zauważa, Karol IV jest w Czechach bohaterem książek, filmów, a nawet dowcipów. Należałoby jeszcze dodać, że do aktualizacji dziedzictwa karlowskiego w ogólnej świadomości w Czechach przyczyniły się na dużą skalę zakrojone obchody siedemsetletniej rocznicy urodzenia władcy w $2016 \mathrm{r}$.

W każdej historii narodowej możemy wyróżnić okresy, które cieszą się szczególnym zainteresowaniem i wokół których stopniowo nagromadziło się wiele, nieraz ze sobą sprzecznych, koncepcji interpretacyjnych, jak również stereotypów i mitów historycznych. Taką pozycję ma już od czasów wielkiego czeskiego historiografa Františka Palackiego epoka husycka. Petr Jokeš, przy wykorzystaniu najnowszej czeskiej literatury przedmiotu, opisuje ją (s. 117-143) rzeczowo, unikając z jednej strony heroizacji i mitologizacji, przedstawiając husytyzm jako niejednolity, wewnętrznie zróżnicowany ruch, z drugiej zaś wskazując na jego niewątpliwe walory, w postaci oryginalnych myślicieli husyckich (Jan Hus, Petr Chelčický), innowacji w dziedzinie sztuki wojennej (Jan Žižka) lub na skalę europejską bezprecedensowych kompaktatów bazylejskich, będących ważnym krokiem w stronę nowoczesnej tolerancji religijnej.

Szereg wyzwań interpretacyjnych stawia przed badaczem także opis antyhabsburskiego powstania czeskich stanów, zmierzenie się z mitem historycznym bitwy na Białej Górze oraz zrównoważona ocena okresu kontrreformacji na ziemiach czeskich (s. 168-196). Niejednoznaczność oceny opisywanych wydarzeń w zależności od przyjętej perspektywy konfesyjnej, a później także narodowej wybrzmiewa dosyć wyraźnie dzięki zastosowaniu przez autora charakterystycznego dla epoki języka w nazwach rozdziałów: „Ohydna rebelia” przywołuje ocenę powstania czeskich stanów z perspektywy panującej dynastii, „Mroki” zaś odwołują się do negatywnego postrzegania okresu baroku, który czasowo nakłada się z kontrreformacją, przez czeski nacjonalizm XIX i XX w. Należy się zgodzić z autorem, że lata 1648-1740 to okres niejednoznaczny, w którym łączą się procesy politycznej marginalizacji Czech i zaniku wolności wyznania z ciekawymi dokonaniami na polu kultury, reprezentowanymi przez muzykę, sztuki plastyczne i architekturę.

Około jednej trzeciej objętości omawianej książki tworzy opis historii Czech w XX w. Ze względu na popularnonaukowy charakter pracy takie rozwiązanie wydaje się słuszne, gdyż dzieje najnowsze cieszą się zazwyczaj największym zainteresowaniem szerokiego grona czytelników. Do najciekawszych rozdziałów tej części należą te, które są poświęcone międzywojennej Czechosłowacji (s. 271-316). Jak 
autor słusznie stwierdza, okres tzw. Pierwszej Republiki (1918-1938) „przez długie lata był - słusznie czy nie - w czeskiej wyobraźni masowej czymś w rodzaju złotego wieku, utraconego raju; nieosiągalnym dla późniejszych czasów wzorcem wolności, demokracji i dobrobytu" (s. 271). Jokeš przedstawia czytelnikowi zrównoważony opis politycznej, społecznej, gospodarczej oraz kulturowej historii międzywojennej Czechosłowacji, poruszając takie tematy jak skomplikowana struktura narodowościowa młodego państwa, wynikająca z niezbyt fortunnego skombinowania zasady prawa historycznego i prawa naturalnego przy wytyczaniu jego granic; dalej czytamy o niebywałym rozwoju gospodarczym (do końca lat dwudziestych), który symbolizuje koncern obuwniczy Bat'a, oraz o zróżnicowanym życiu kulturalnym w międzywojniu reprezentowanym przez bogate życie literackie (Jaroslav Seifert, Karel Čapek) i artystyczne, w dziedzinie sztuk plastycznych (Otto Gutfreund, Václav Špála) oraz architektury (Bohuslav Fuchs, Arnošt Wiesner). Za udany należy uznać także rozdział „Walka o przeżycie” (s. 301-316), w którym autor opisuje ostatnie lata istnienia międzywojennej Czechosłowacji (zwłaszcza okoliczności podporządkowania się przez rząd czechosłowacki traktatowi monachijskiemu we wrześniu 1938 r.) i przekonująco obala pogląd (pojawiający się czasami w Czechach, jak również w Polsce), jakoby Czesi wykazali się w 1938 r. mniejszą odwagą niż Polacy w 1939 r. lub inne narody później.

Jak już zaznaczono na początku, poza zainteresowaniem Petra Jokeša pozostały stosunki czesko-polskie. Wyjątek stanowią jedynie te przypadki, kiedy relacje czesko-polskie w jakiś sposób wpłynęły na dzieje Czech. To dotyczy oczywiście dawnych sojuszy, związków i umów dynastycznych (ślub Mieszka I i Dobrawy w latach 965-966, s. 46; objęcie tronu polskiego przez Wacława II w 1300 r., s. 87; panowanie Jagiellonów w Czechach w latach 1471-1526, s. 144-154), jak również konfliktów zbrojnych, do których w przeszłości dochodziło pomiędzy Czechami i Polską (zajęcie Pragi przez Bolesława Chrobrego w latach 1003-1004, s. 51; najazd Brzetysława I na Gniezno w 1038 lub 1039 r., s. 52).

O ile dawne konflikty można tłumaczyć średniowiecznym modelem sprawowania władzy, o tyle ich bardziej współczesne odsłony mogą nastręczać pewne kłopoty, jak chociażby przypadek czechosłowacko-polskiego konfliktu zbrojnego o Śląsk Cieszyński w 1919 r. (s. 275-277). Autor jako źródło konfliktu przekonująco wskazuje wzajemnie sprzeczną legitymizację roszczeń terytorialnych Czechów i Polaków prawa historycznego (Śląsk Cieszyński był częścią państwa czeskiego od 1292 r.) i prawa naturalnego (na spornym obszarze przeważała ludność etnicznie polska). Jak badacz słusznie stwierdza, konfliktu nie należy traktować dziś w kategoriach spra- 
wiedliwości lub niesprawiedliwości (więcej lub mniej korzystnego zysku terytorialnego), gdyż w gruncie rzeczy chodziło o zderzenie dwóch egoizmów narodowych. Rozbieżność interesów obu państw trwała przez cały okres międzywojenny, co autor dobrze podsumowuje, pisząc, że „w Pradze, tak samo jak w Warszawie, ulegano iluzjom o własnym znaczeniu i jednocześnie postrzegano sąsiada jako «państwo sezonowe», z którym nie warto nawiązywać bliższych stosunków - co zresztą przyczyniło się do tego, że ostatecznie sezonowymi okazały się oba państwa” (s. 286).

W opisie wydarzeń związanych z inwazją wojsk Układu Warszawskiego do Czechosłowacji i jej następstw (s. 373-379) zabrakło chociażby krótkiej wzmianki o polskim współudziale. Jest to temat interesujący, oczywiście nie ze względu na jakiś istotny wpływ Polski na rozwój wydarzeń w Czechosłowacji (pozornie internacjonalny charakter interwencji był sprytnym zabiegiem Moskwy), ale pod kątem percepcji tego faktu w polskiej, co ciekawe raczej nie w czeskiej, wyobraźni zbiorowej; pewien kłopot wizerunkowy, z którym piszący te słowa spotykał się jeszcze po ponad trzydziestu latach od wydarzeń 1968 r. w wypowiedziach polskich rozmówców. Na krótką wzmiankę zasługiwałaby także działalność Solidarności Polsko-Czechosłowackiej w latach osiemdziesiątych XX w., która przyczyniła się do zmian ustrojowych w Czechosłowacji w 1989 r.

Podsumowując, książkę Petra Jokeša należy ocenić jako ważną i potrzebną pracę popularnonaukową, która zapełni lukę na polskim rynku wydawniczym. Autor doskonale orientuje się w realiach czeskich, jak również polskich lub szerzej środkowoeuropejskich, co daje mu szerszą perspektywę oglądu. Praca odznacza się przemyślaną koncepcją - obszerna materia historyczna została zorganizowana według klucza chronologiczno-tematycznego, jak również problemowego. Choć wiodąca perspektywa jest, rzecz jasna, syntetyczna, nie brakuje również analitycznego pogłębienia w miejscach, gdzie jest to potrzebne. Książka została napisana w sposób rzetelny (z wykorzystaniem najnowszej, głównie czeskiej produkcji historiograficznej) i równocześnie klarowny oraz atrakcyjny, co z pewnością zjedna jej szerokie grono czytelników. 
Nadesłano: 4 IV 2021

Zaakceptowano: 6 IV 2021

Mgr Jan Pešina

Instytut Filologii Słowiańskiej

Wydział Filologii Polskiej i Klasycznej

Uniwersytet im. Adama Mickiewicza w Poznaniu

ul. Fredry 10

61-701 Poznań

jan.pesina@wp.pl 